\title{
Forme dell'intreccio per ri-cucire memorie di un antico impianto in Basilicata
}

\author{
Marianna Calia \\ Antonio Conte \\ Roberto Pedone \\ Margherita Tricarico
}

\section{Abstract}

La ricerca, partendo dalla conoscenza di territori e patrimoni fragili in terra Lucana, tenta di ri-configurare una possibile trasformazione per ri-abitare il borgo antico abbandonato della città di Craco, ipotizzando nuove opportunità di valorizzazione culturale, turistica ed economica.

II progetto immagina e disegna un sistema diffuso di piccoli rifugi e luoghi di sosta e fruizione del paesaggio. Queste piccole architetture saranno in grado di donare ai visitatori la più sublime delle esperienze: abitare fra le rocce e addormentarsi sotto le volte scoperte di una città fantasma, fra le rovine di Craco antica ed i calanchi di queste terre. I manufatti disegnati come opere provvisionali e prowisorie, lavorano e si innestano mediante il concetto di 'sospensione' e 'leggerezza', tra i relitti, i vicoli e le strade, gli scheletri delle case, la terra spianata di macerie dei resti di architetture, materiali dell'arte del costruire che un tempo hanno disegnato questi luoghi.

La forma della città e dei materiali architettonici di cui essa si compone hanno caratterizzato il progetto che si è svolto intorno allo studio ed alla realizzazione di prototipi per disegnare dispositivi di attraversamento in legno e ferro per il consolidamento dei ruderi ed essere anche replicabili in altre zone con caratteri e morfologie analoghe.

Parole chiave

Intreccio, eredità, ri-cucire, trasformare, ri-abitare.

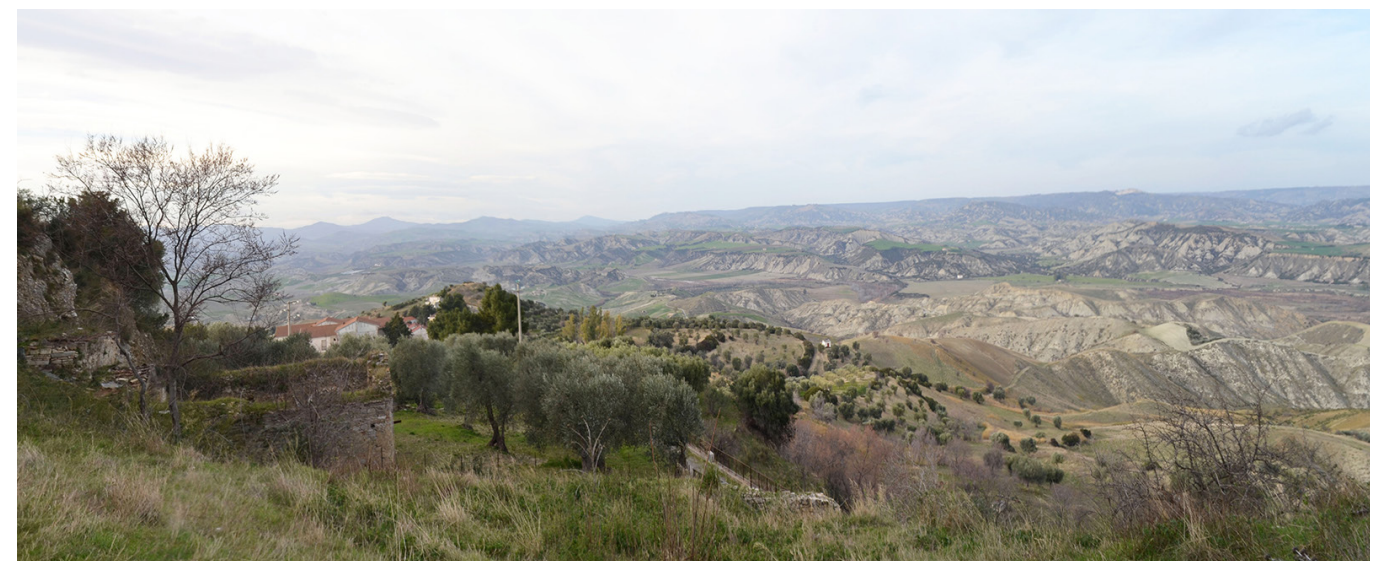




\section{"Fa' attenzione alle forme con cui costruisce il contadino. Perché sono patrimonio tramandato della saggezza dei padri. Cerca però di scoprire le ragioni che hanno portato a quella forma. $[\ldots]$ Non pensare al tetto, ma alla pioggia e alla neve. In questo modo pensa il contadino e di conseguenza costruisce in montagna"}

[Loos 2007, p. 27I]

\section{Conoscenza e stato dell'arte}

Craco sorge nella zona collinare che precede l'Appennino Lucano a metà strada tra il mare ed i monti, a circa 400 metri di quota, nella parte centro occidentale della provincia di Matera. II territorio circostante è caratterizzato da una predominanza di calanchi, profondi solchi scavati in un terreno cretoso modellato dalle acque piovane. L'antico impianto del borgo con le case arroccate intorno ad un torrione quadrato che domina il territorio, risale al XII secolo e nel XVI contava 2.500 abitanti. La rovina di Craco è il risultato di una successione di eventi calamitosi avvenuti in epoche differenti, che la storia ha intrecciato in un progressivo ed irreparabile dissesto ed abbandono.

L'antica fortezza normanna poggia le proprie basi su un solido conglomerato minerale, circondato da imponenti masse di argilla che si distendono sull'intera campagna circostante. Cresciuta attorno alla propria torre, Craco si costruisce con un peso sempre più significativo sulle argille sottostanti, definendo un sistema più delicato e critico come punto di equilibrio. Le prime testimonianze storiche sui dissesti avvenuti a Craco, risalgono a metà dell'Ottocento, quando, nel 1870 e nel 1886 vengono registrati i primi movimenti franosi che investono l'area. Notizie documentate descrivono la costruzione di un muro di sostegno ad archi per la strada statale 103, che tuttora delimita il paese. Tale opera venne eretta in prossimità del centro storico interessato dalla più attiva delle tre grandi ed antiche frane che coinvolsero il versante sud. La frana che portò al progressivo abbandono del borgo, ebbe inizio con il crollo delle mura principali nel dicembre del 1963, Craco iniziò a essere evacuata e parte degli abitanti si trasferirono a valle in località Craco Peschiera. Nel 1972 un'alluvione peggiorò ulteriormente la situazione, impedendo un'eventuale ripopolazione del centro storico e dopo il terremoto del 1980 Craco venne definitivamente abbandonata.

Il posizionamento di sensori, ad oggi, ha messo in evidenza che il centro storico si trova in condizioni di stabilità.

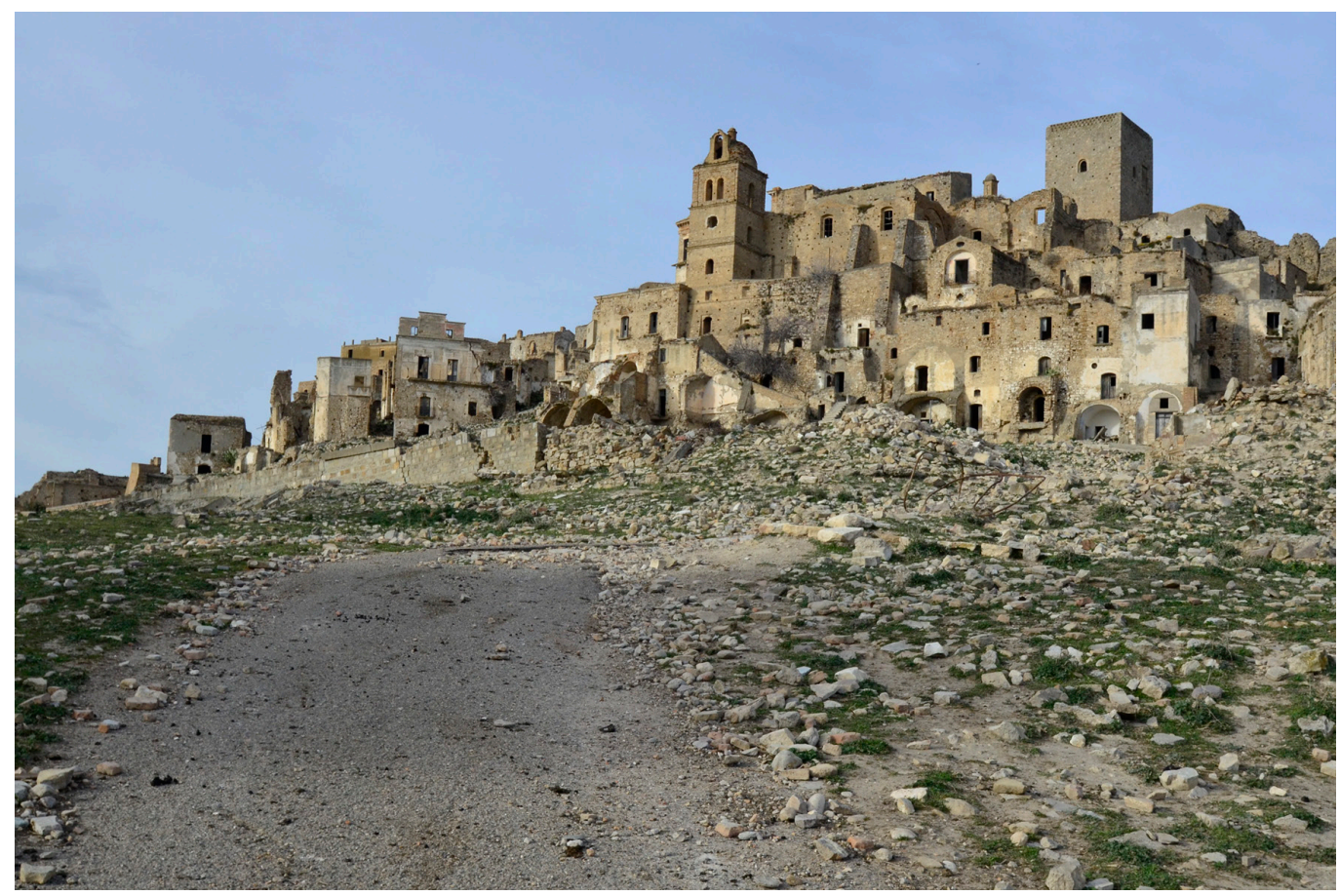


Oggi del borgo antico non rimangono che rovine: gli unici edifici discretamente integri sono quelli costruiti nella parte più alta, al di sopra dello sperone roccioso naturale, mentre la gran parte dell'edificato è ridotto a macerie; edifici pericolanti con profonde fenditure e dissesti strutturali che ne hanno compromesso profondamente la stabilità rendendone estremamente complessa la messa in sicurezza.

Questo grande manufatto si presenta oggi come un'unica composizione, una scultura aggrappata ad una cresta di un massiccio che si erge maestoso nelle valli circostanti. L'idea centrale per Craco 'città fantasma', come tante altre realtà del nostro sud perdute nell'oblio dell'abbandono, occupa nella ricerca internazionale una posizione importante. In particolare nell'immaginario collettivo ed in quello di moltissimi registi e fotografi [I], Craco rappresenta una misteriosa e sfuggente opportunità di esperienza fra la vita che è fluita in un luogo ed il fascino che questo può esercitare perché drammaticamente abbandonato. Craco è cresciuta con una forza incredibile di resistenza e di appartenenza al sito, fra pinnacoli di roccia e creste d'argilla, diventando oggi più che mai l'archetipo della città fantasma: bruciata dal sole e dai rigidi inverni, un corpo unico di case e palazzi fra loro aggrappati secondo una composizione che appare espressiva ed affascinante, quasi una scultura di abitazioni scoperchiate, volte interrotte e campanili in rovina.

La sperimentazione progettuale tenta di strappare questo luogo da un presente che non gli appartiene, intrappolato fra le pieghe del passato e il tempo dell'abbandono. Questo carattere e la natura del luogo, possono mutare proprio attraverso la prefigurazione nella ricerca di una nuova vita, una trasformazione in un diverso organismo che può accogliere e ricucire, trasmettere profonde emozioni e permettere ogni anno a migliaia di turisti di immergersi, dopo un viaggio difficile, guidati dalla scoperta, a volte curiosità, nella meravigliosa esperienza di questa 'città fantasma'.

Gli interni delle case contengono ancora elementi di vita quotidiana e raccontano storie interrotte: bottiglie coperte di polvere su camini freddi, sedie e cesti di vimini consumati dal tempo, raccontano di famiglie attorno al focolare e spazi domestici vissuti secondo i ritmi dalla natura, delle stagioni, delle coltivazioni e degli animali. Pinnacoli e guglie rivestite da ormai rade tessere di maiolica, evocano di un sobrio benessere, di una città capace di una sua bellezza e monumentalità, come il campanile dell'antica chiesa. Questo luogo, da cui deriva l'ispirazione iniziale della ricerca e del progetto, rappresenta un'esperienza umana costruita e ben definita nel tempo a cui il nostro lavoro tenta una risposta plausibile per accedere alle armonie, alle emozioni accessibili da ciascun individuo che lo 'abiterà'. (M.C.).

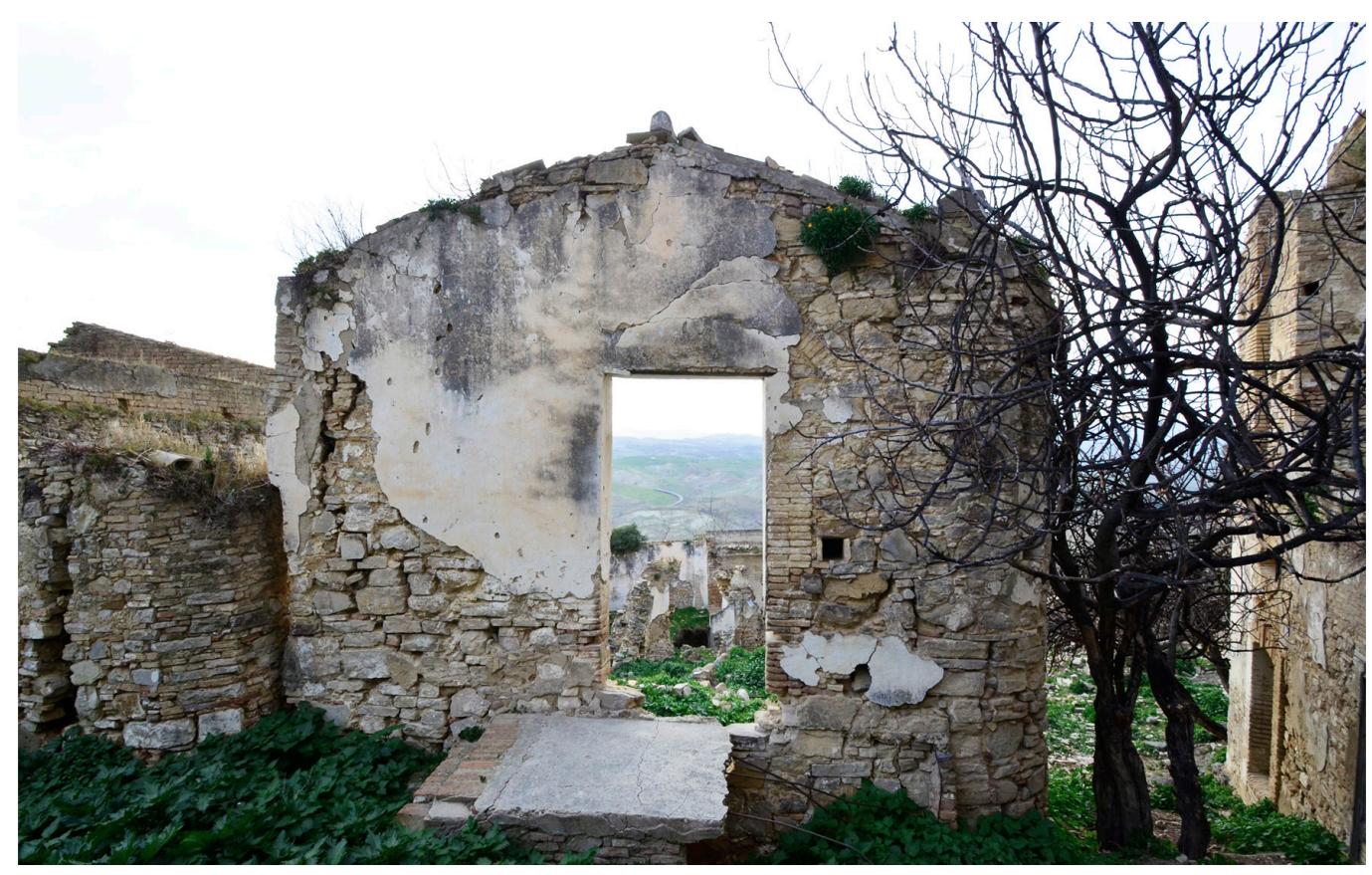




\section{Premesse metodologiche e senso logico della ricerca}

Riconosciuto come geo-sito di interesse scientifico, Craco poggia le sue fondamenta su rocce sedimentarie (ghiaie, sabbie e argille) caratterizzate da forme suggestive e nell'intorno, terrazzi fluviali e calanchi disegnano in modo suggestivo il paesaggio. L'architettura può, attraverso nuove 'forme dell'intreccio', tentare azioni ed individuare manufatti per ri-cucire queste profonde ferite. Rapportarsi alla memoria di questo antico impianto per poter continuare a frequentarlo, vuol dire strutturare luoghi di un percorso di conoscenza della storia umana che, attraverso la risposta di progetto, prefigura soluzioni adeguate e sostenibili.

La conoscenza e la comprensione delle origini e della storia del dissesto, grazie anche alla collaborazione con i colleghi geologi, sono state punto di partenza per ideare architetture 'consapevoli', capaci di misurarsi con le caratteristiche profonde del luogo. II lavoro di ricerca e sperimentazione progettuale, tenta di ri-disegnare percorsi di ri-connessione attraverso piccole architetture e segni, quasi come eventi, che permettano di scoprire lo scorrere dell'opera umana, individuare le tracce di ogni persona che nella storia ha frequentato un ambiente, un vicolo, una casa, una chiesa, un palazzo, la torre di guardia normanna. Ogni cosa potrà essere osservata per comprendere un particolare valore della storia della sua esistenza. II progetto di architettura, partendo da una ricerca più ampia sui territori e patrimoni fragili di questa terra [2], tenta di prefigurare qualcosa di intangibile ma presente, di misterioso ma percepibile, per ri-configurarne una possibile trasformazione che apre a nuove opportunità di valorizzazione culturale, turistica ed economica.

I disegni provano ad immaginare e ideare un sistema diffuso di piccoli rifugi in grado di permettere ai visitatori la più sublime delle esperienze: abitare fra le rovine e addormentarsi sotto le volte scoperte di una città fantasma, fra le rovine antiche ed i calanchi di queste terre. Nuovi rifugi temporanei in legno e ferro, fra le trame di strade scoscese e viottoli sassosi, tra pareti ridotte a vele, cieli azzurri e notti stellate.

Il progetto è articolato attraverso un itinerario rappresentativo di immagini in una passeggiata che con 'leggerezza' ed una concreta 'consistenza' percorre luoghi e resti di città. La grande opera dei manufatti e la montagna, sono un orizzonte immobile e drammatico ma il percorso e gli elementi dell'attraversamento sono in continua trasformazione, in un'incessante virtù dello spostamento dello sguardo.
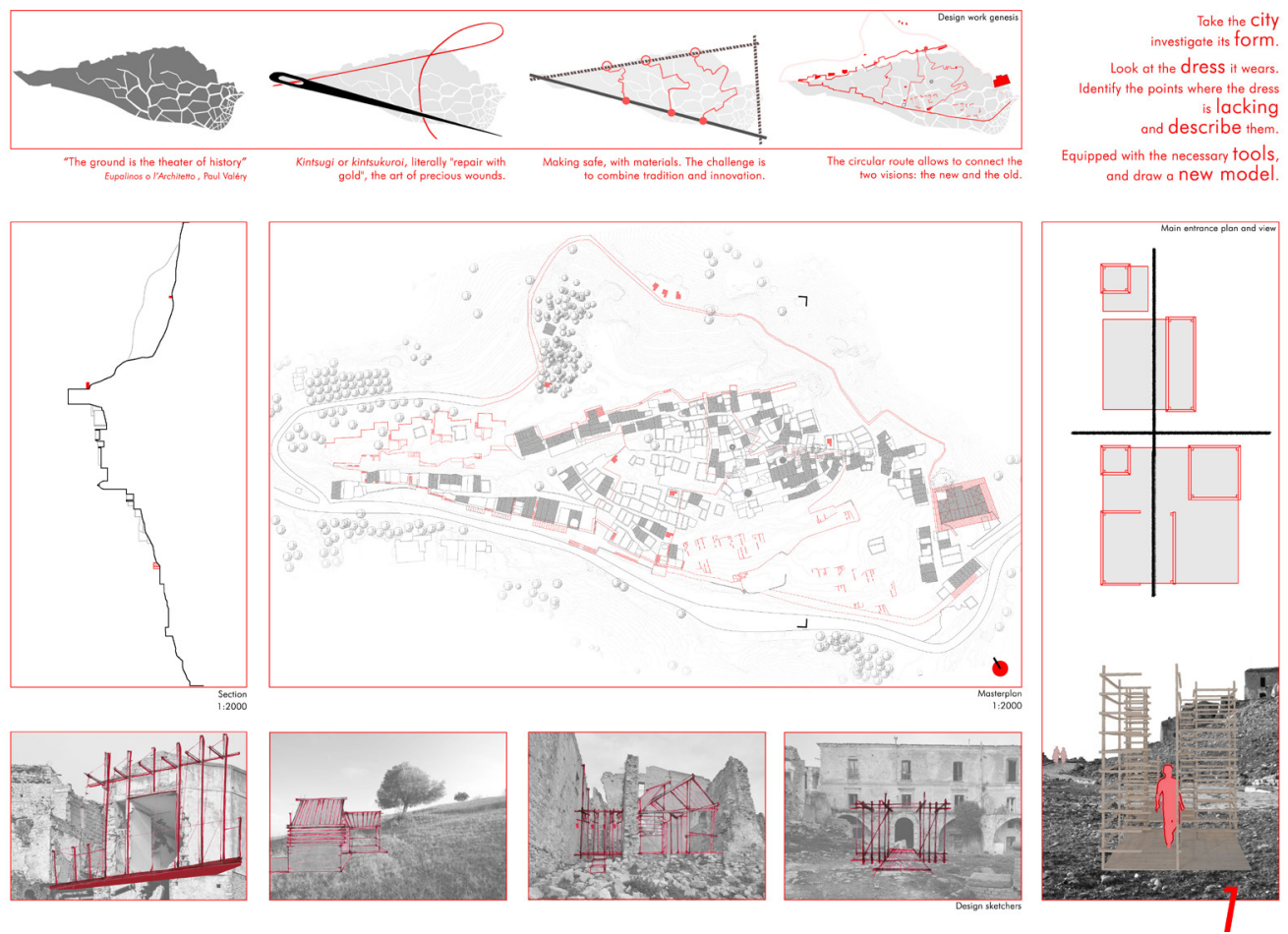
II mutamento della forma della città a causa di eventi catastrofici, sia naturali che di matrice antropica, rappresenta uno dei temi sui cui oggi l'architetto è chiamato a riflettere con maggiore frequenza. La questione dell'Heritage attraversa ogni lavoro di ricerca e progetto contemporanei. Si registra, in questi casi, la perdita del ruolo delle città in queste terre fragili, distrutte e abbandonate, che perdono la loro vocazione di luoghi dell'abitare, per divenire luoghi per la visita rapida del turista o per la sosta del viaggiatore attento. Ci si chiede, allora, quale sia il senso di ri-abitare questi luoghi le cui pietre e le architetture, narrano vicende di storie antichissime. Le pietre delle architetture che compongono questi nuclei urbani, sono fili di un ricamo della memoria dei luoghi, intrecci di storie, reti di relazioni, lacci e nodi che congiungono pezzi di vita e di storia incredibili tenuti insieme dal progetto di Architettura.

Questa ideazione del progetto non attiene ai contenuti grafici o del segno, ma ad una sorta di accumulazione delle conoscenze che le traiettorie dei percorsi e delle viste porrà il visitatore a connettersi con la memoria e l'arte fissata per sempre nei materiali e nelle fabbriche, coscienti di quanto affermato da Paul Valéry che "il suolo è il teatro della storia". (A.C.).
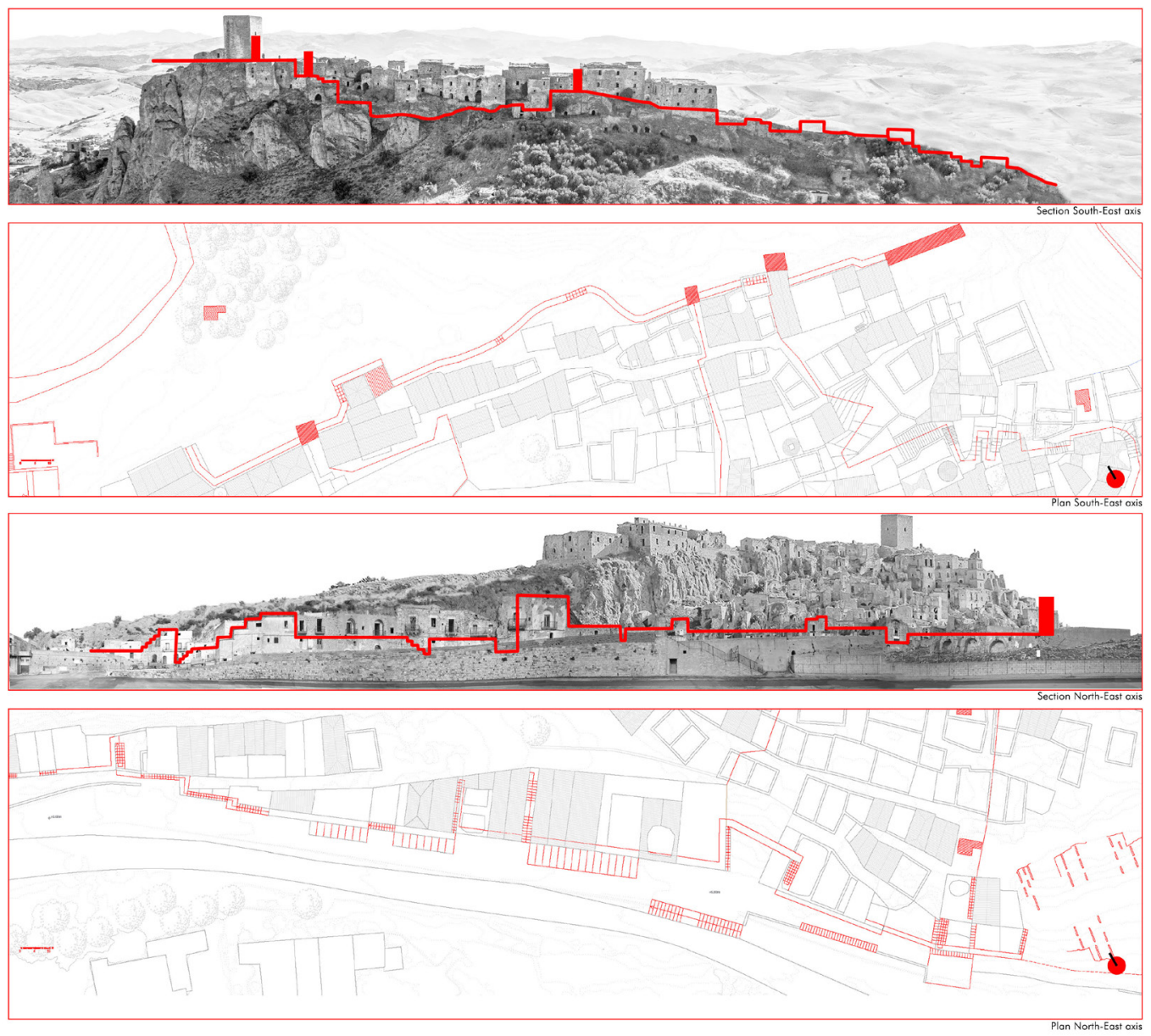

\section{Progetto di ri-disegno per ri-cucire memorie di una città antica}

Il processo di genesi ed evoluzione di questo progetto di ricerca, nasce dal riconoscimento della memoria dei luoghi come 'fatti urbani' fondativi e caratterizzanti, declinando il progetto di ricucitura di architetture in rovina, mediante metodi costruttivi contemporanei e sostenibili. Si intende reinterpretare il gesto di 'ricucire la città' mediante opere provvisorie e di messa in sicurezza di carattere temporaneo, disegnate studiando forme e modelli riconoscibili nelle tracce della memoria dei luoghi. 
II gesto di 'ricucire' parti di città disgregata, fa riferimento ad un'antica pratica giapponese: il kintsugi, che evidenzia le fratture, le impreziosisce e aggiunge valore all'oggetto rotto; kin vuol dire oro e tsugi ricongiunzione.

Si intende abbracciare il danno, evidenziare le linee di frattura, impreziosire e aggiungere valore all'oggetto architettonico e urbano, rendendo la fragilità un punto di forza e perfezione. Scegliendo di riparare cosa è stato danneggiato, non solo se ne riconosce il valore, ma si sviluppa un attaccamento ancora più forte alla sua materia. Intricato e fitto è il ricamo delle circostanze, dei manufatti e dei vicoli che compongono il nucleo ed il crinale urbano di Craco così come di numerosissimi centri storici della Basilicata e del Meridione d'Italia.

Gli obiettivi del progetto sono la fruibilità del borgo attraverso la costruzione di opere provvisionali di consolidamento, che allo stesso tempo fungano da 'spazio' da attraversare in sicurezza, e la valorizzazione intesa come atto esperienziale e testimoniale di percorrenza di un'antica sensazione di vita tra i vicoli impraticabili e resi irriconoscibili dai crolli. Attualmente il sito presenta un unico itinerario di percorrenza in sicurezza, che giunge a ridosso della torre normanna. Si tratta un percorso univoco, dal quale non è possibile apprezzare la complessa e articolata topografia storica dei luoghi. La fruibilità che si intende raggiungere con il progetto, mira al superamento delle difficoltà oggettive di raggiungimento di alcuni punti della città fantasma, per cui si affida alle opere provvisionali il compito di garantire la sicurezza per chi percorre i luoghi. Archi in legno, puntoni, cerchiature, impalcati, piccoli trabattelli, sono queste alcune delle 'macchine' utilizzate per inerpicarsi tra i resti delle antiche vie di Craco. Questi lunghi ed articolati dispositivi lignei che sfiorano, sorreggono e in alcuni casi avvolgono e attraversano le pareti fragili di alcune piccole case, si aprono, lì dove le condizioni al contorno lo permettono, a dei piccoli rifugi lignei di fortuna, leggeri ripari per la notte, dai quali osservare la volta stellata lontano dalle luci delle città. II carattere e la semplicità di messa in opera, la tecnica di lavorazione di travi, travicelli e montanti in legno di cerro e abete rosso, restituisce il dialogo perso con la tradizione costruttiva. Ne consegue che le opere provvisionali non appaiono più solo nel momento della costruzione e manutenzione degli edifici, ma si fanno 'spazio' e occasione di valorizzazione di luoghi difficilmente raggiungibili.

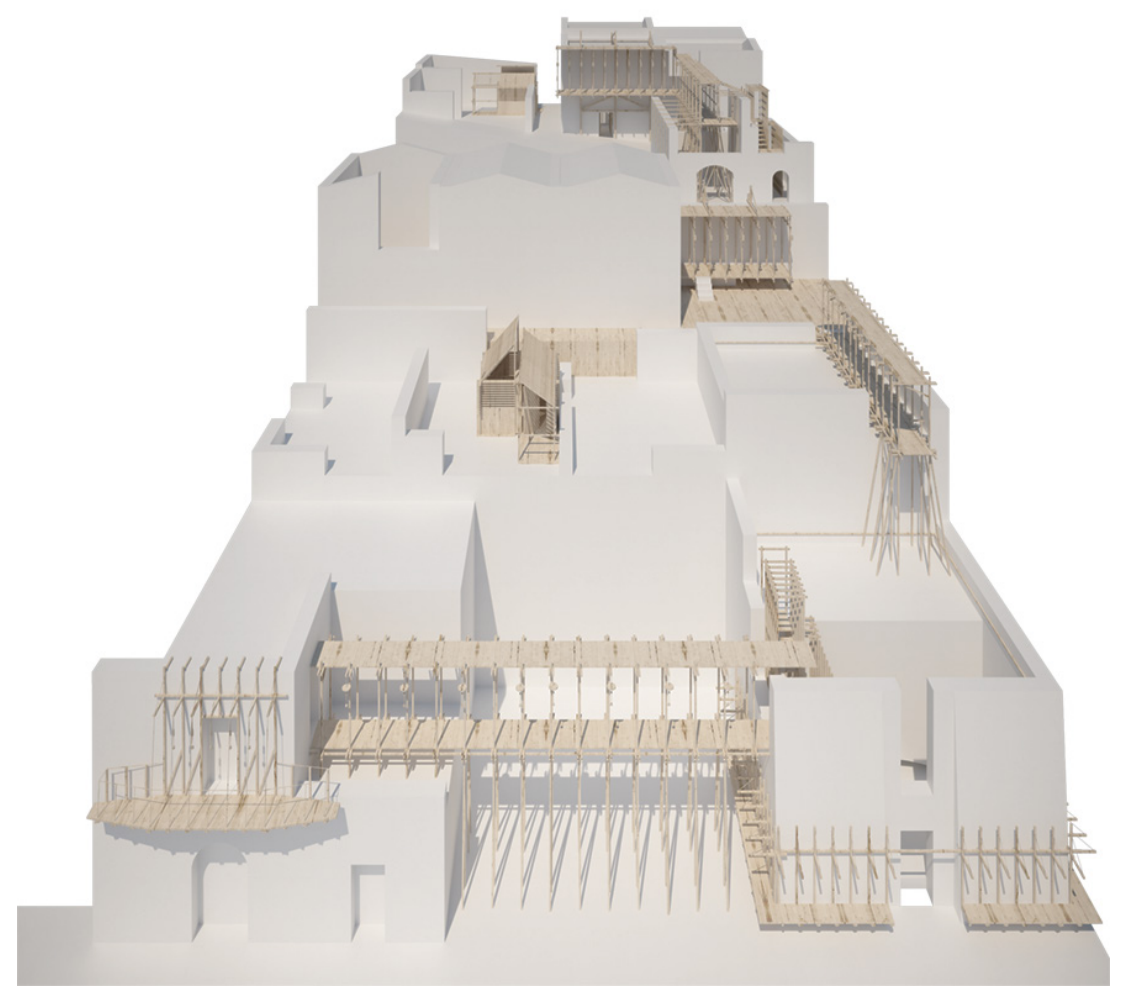



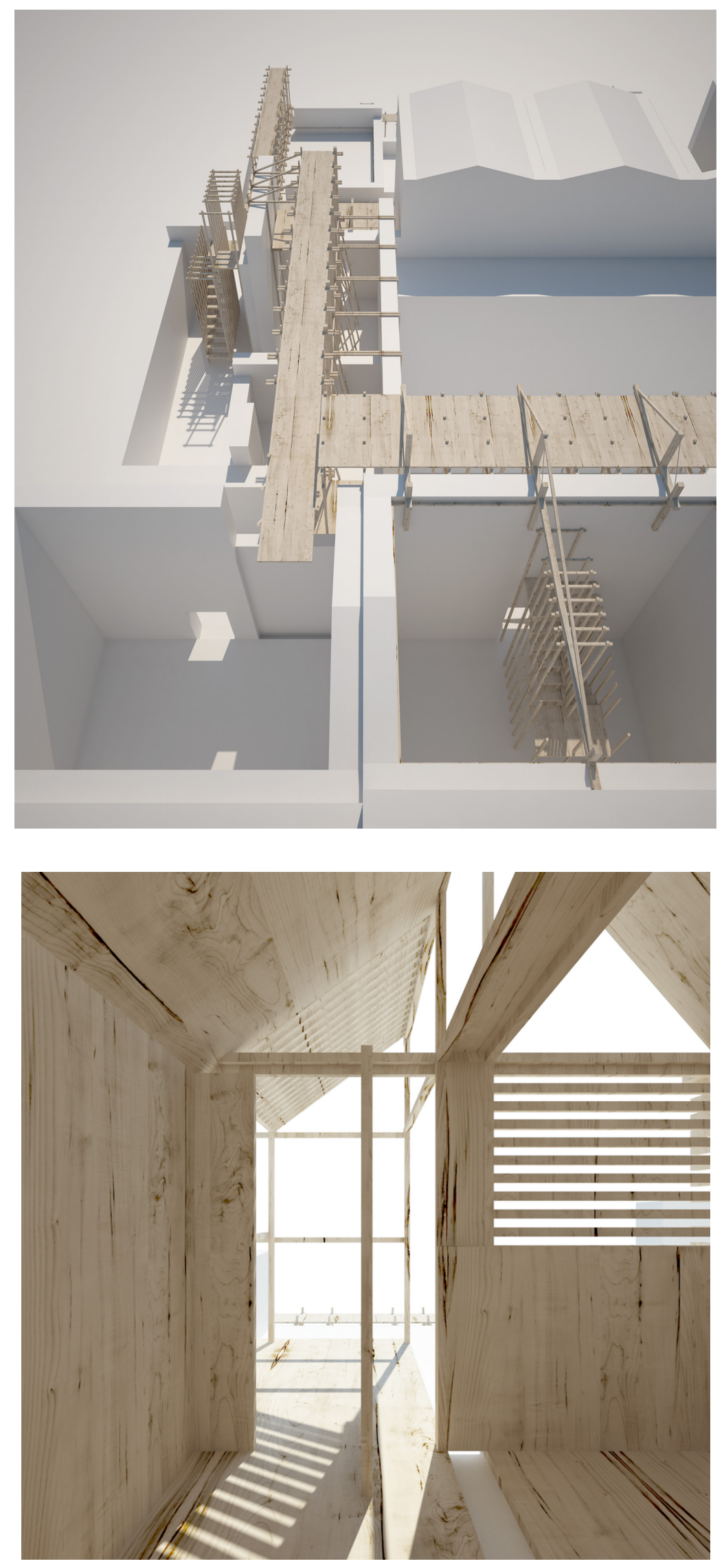
I manufatti disegnati come opere provvisionali e provvisorie, lavorano e si innestano mediante il concetto di 'sospensione' e 'leggerezza' tra i relitti, i vicoli e le strade, gli scheletri delle case, la terra spianata di macerie dei resti di architetture, materiali dell'arte del costruire, che un tempo hanno abitato questi luoghi.

Dopo aver indagato la forma della città e dei materiali di cui essa si compone, il progetto si è concentrato sullo studio e nella realizzazione di prototipi tridimensionali per disegnare dispositivi di attraversamento e consolidamento delle architetture e dei ruderi, che possa essere anche replicabile in altre zone aventi caratteri riconosciuti simili.

Il progetto si articola, dunque, attraverso la definizione di percorsi di attraversamento dell'intero centro storico, che conducono a luoghi di sosta temporanea per il viaggiatore, piccoli rifugi, spazi per il ristoro e la contemplazione del paesaggio e la progettazione di piccole stanze costruite in continuità con solchi della roccia, nella parte più solida staticamente che risulta essere anche il punto di vista più suggestivo sulla vallata sottostante.

Il paesaggio è una costruzione antropica in divenire, in continua evoluzione. II progetto, la sua ideazione, lavora sul limite fisico tra architettura e forma della città (paesaggio), per innestare l'architettura contemporanea tra le pieghe della roccia che la compone. Spingersi oltre il limite fisico e storico attra-verso il paesaggio naturale.

Dalla roccia emergono dunque frammenti di micro-architetture leggere in legno e acciaio corten che, con la nuova ideazione e trasformazione dell'uso di questo patrimonio, di queste architetture, si configurano come innesti e intrecci in un continuum con la costruzione della città antica.

A sud della città vecchia, in prossimità della strada comunale Craco-Montalbano Jonico, si articola un grande casolare disposto su tre piani. La sua posizione strategica e le dimensioni adatte ad accogliere un numero considerevole di persone, gli conferiscono il carattere di uno spazio pubblico con servizi misti accessori quali accoglienza turistica, ristorante, biblioteca e spazio espositivo. Questo edificio, ancora integro strutturalmente, mantiene la sua conformazione formale e materica complessiva, integrata da opere provvisionali in legno che arricchiscono e articolano l'edificio garantendo un disegno armonico tra l'architettura storica e il paesaggio circostante. Una struttura leggera, in listelli di legno intrecciati, circonda il piano terra diventando cinta e basamento dell'intero edificio che acquista visibilità formale e sostegno tettonico; essa contamina anche gli spazi interni e ne distribuisce le geometrie e le destinazioni d'uso.

Fig. 8. Abaco degli elementi delle opere provvisionali, di contrafforte e consolidamento, che caratterizzano i percorsi urbani.
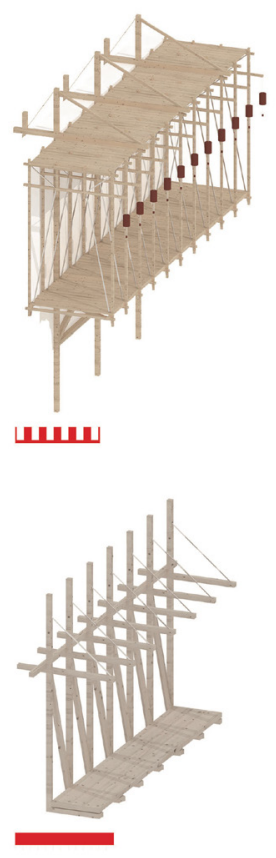
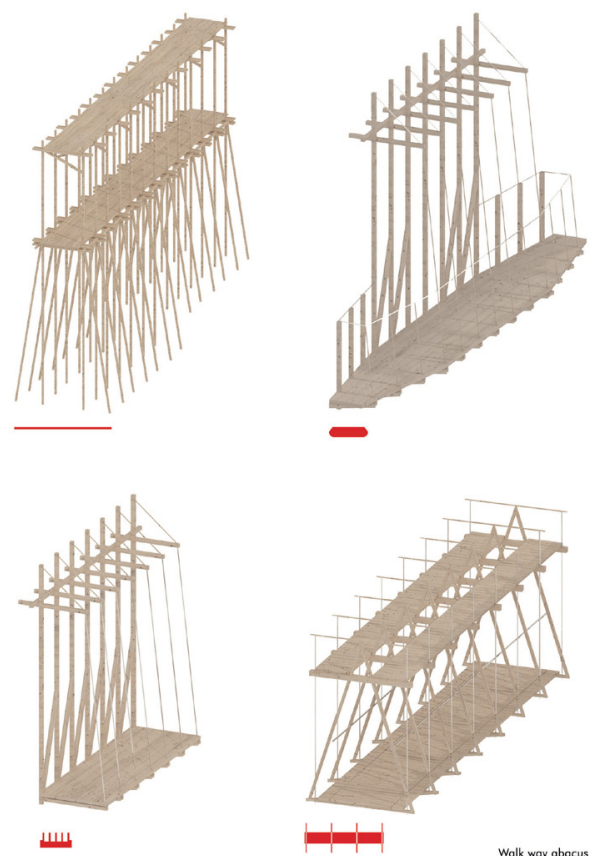
Fig. 9. Planimetrie, sezioni e viste dei piccoli rifugi incastonati tra le rocce, sul crinale.


New Architectures arise from the rock, as the
construction of the city was born from it.

The refuge by its nature, is nothing more than giphysical Architecture.

The contact with the earth. Built and natural part.
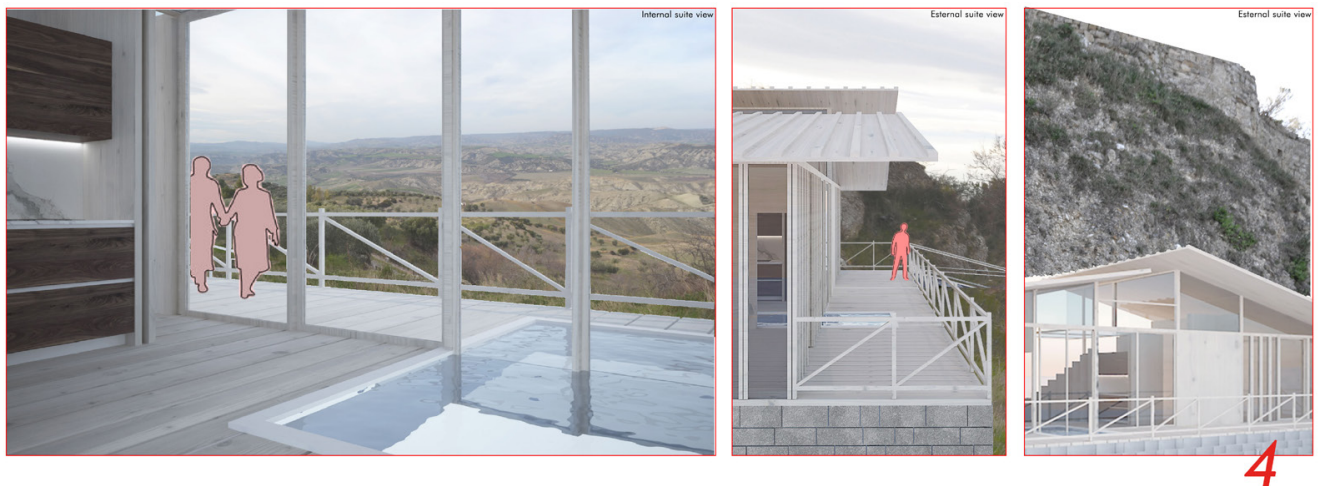

Nella parte opposta della città vecchia, a nord e in adiacenza al crinale, prendono forma tre rifugi destinati ad ospitare i visitatori. La roccia esistente collabora alla modellazione dello spazio architettonico, che se ne appropria e ne costituisce forma. La nuova struttura in legno, quindi, nasce e si articola aggrappata alla materia del luogo, seguendo lo stesso principio delle architetture delle città Lucane, quando si costruiva in sintonia con il territorio, sottraendo e aggiungendo lo stesso materiale per costruire 'collaborando con la terra' (R.P., M.T.)
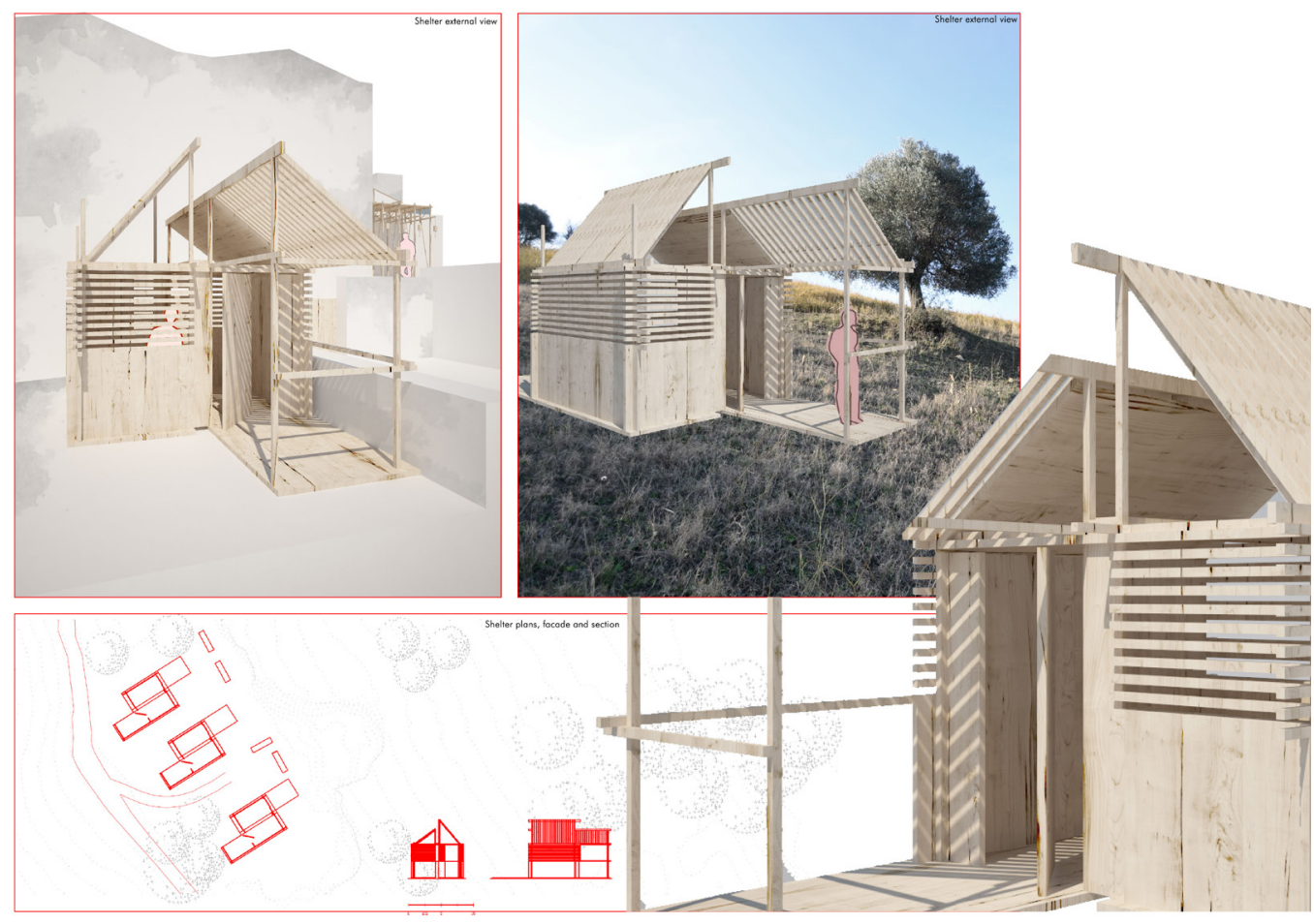


\section{Note}

[I] Si ricordano scene di “La Passione di Cristo" di Mel Gibson e di "Quantum of Solace" di Marc Forster, girate nei territori di Craco.

[2] La ricerca è parte di attività di sperimentazione progettuale condotta nell'ambito del Laboratorio di Progettazione 5: "Architettura ed Eredità del Costruito" e del modulo di "Forma e conoscenza del patrimonio architettonico", del CdL in Architettura del Dipartimento DiCEM di Matera, Università degli Studi della Basilicata. II tema del Laboratorio è "Architettura e patrimoni fragili di antico impianto in Basilicata". Al conseguimento degli obiettivi raggiunti e alla stesura del testo e delle immagini contenute in questo saggio, hanno contribuito a vario titolo: i dottorandi Roberto Blasi, Roberto Pedone e Margherita Tricarico e gli architetti Rossella Laera, Anna Lovino, Mara Manicone, Lucia Nardiello e Francesca Sbano, coordinati dal prof. Arch. Antonio Conte e dalla Ph.D. Arch. Marianna Calia, rispettivamente il responsabile e la tutor del Laboratorio.

\section{Riferimenti bibliografici}

Pedío Tommaso (1990). Centri scomparsi in Basilicata. Potenza: Osanna Edizioni.

Pasolini Pier Paolo, Brunatto Paolo (1973). Orte. La forma della città. docu-film RAl.

Martí Arís Carlos (20 I I). La cèntina e l'arco. Pensiero, teoria, progetto in architettura. Milano: Christian Marinotti Edizioni.

\section{Autori}

Marianna Calia, Università della Basilicata, marianna.calia@unibas.it

Antonio Conte, Università della Basilicata, antonio.conte@unibas.it

Roberto Pedone, Università della Basilicata, roberto.pedone@unibas.it

Margherita Tricarico, Università della Basilicata, margherita.tricarico@unibas.it

Per citare questo capitolo: Calia Marianna, Conte Antonio, Pedone Roberto, Tricarico Margherita (2020). Forme dell'intreccio per ri-cucire memorie di antico impianto in Basilicata/Twine forms to re-stitch memories of an ancient plan in Basilicata. In Arena A., Arena M., Brandolino R.G.,
Colistra D., Ginex G., Mediati D., Nucifora S., Raffa P. (a cura di). Connettere. Un disegno per annodare e tessere. Atti del $42^{\circ}$ Convegno Internazionale Colistra D., Ginex G., Mediati D., Nucifora S., Raffa P. (a cura di). Connettere. Un disegno per annodare e tessere. Atti del $42^{\circ}$ Convegno Internazionale
dei Docenti delle Discipline della Rappresentazione/Connecting. Drawing for weaving relationships. Proceedings of the 42 th International Conference of Representation Disciplines Teachers. Milano: FrancoAngeli, pp. 975-994. 


\title{
Twine Forms to Re-Stitch Memories of an Ancient Plan in Basilicata
}

\author{
Marianna Calia \\ Antonio Conte \\ Roberto Pedone \\ Margherita Tricarico
}

\section{Abstract}

The research, starting from the knowledge of territories and fragile heritages in Lucana land, tries to re-configure a possible transformation to re-inhabit the abandoned ancient city center of Craco, hypothesizing new opportunities for cultural, tourist and economic enhancement.

The project imagines and designs a widespread system of small refuges and places to stop and enjoy the landscape. These small architectures will be able to give visitors the most sublime of experiences: living among the rocks and falling asleep under the uncovered vaults of a ghost town, among the ruins of ancient Craco and the badlands of these lands. The artifacts designed as temporary and temporary works, work and graft through the concept of 'suspension' and 'lightness', between the wrecks, alleys and streets, the skeletons of the houses, the flattened earth of rubble of the remains of architecture, materials of the art of building that once designed these places.

The shape of the city and of the architectural materials of which it is composed characterized the project that took place around the study and the creation of prototypes to design wooden and iron crossing devices for the consolidation of the ruins and also to be replicable in other areas with similar characters and morphologies.

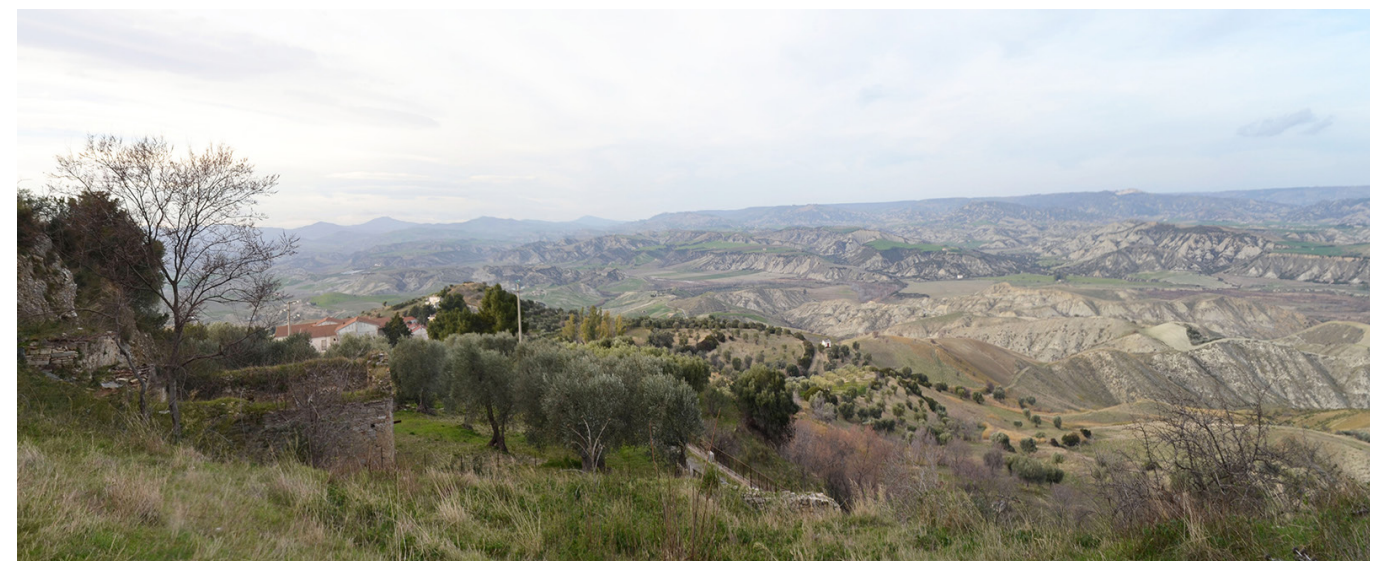




\section{"Fa' attenzione alle forme con cui costruisce il contadino. Perché sono patrimonio tramandato della saggezza dei padri. Cerca però di scoprire le ragioni che hanno portato a quella forma. [... Non pensare al tetto, ma alla pioggia e alla neve. In questo modo pensa il contadino e di conseguenza costruisce in montagna'}

[Loos 2007, p. 27I]

\section{Knowledge and state of the art}

Craco is located in the hilly area that precedes the Lucanian Apennines, halfway between the sea and the mountains, at about 400 meters above the sea level, in the central western part of the province of Matera. The surrounding area is characterized by a predominance of badlands, deep furrows dug in a clay soil shaped by rainwater. The ancient layout of the village with the houses perched around a square tower overlooking the area, dates back to the I 2th century and in the I 6th century it counted 2,500 inhabitants. Craco ruin is the result of a succession of calamitous events occurred in different eras, which history has intertwined in a progressive and irreparable disruption and abandonment.

The ancient Norman fortress places its foundations on a solid mineral conglomerate, surrounded by imposing masses of clay that stretch over the entire surrounding countryside. Grown around its tower, Craco is built with an increasingly significant weight on the underlying clays, defining a more delicate and critical system as a point of balance.

The first historical evidence of the failures that occurred in Craco, dates back to the mid-nineteenth century, when, in 1870 and 1886, the first landslides that hit the area were recorded. Documented news describes the construction of an arched retaining wall for the highway 103, which still delimits the town. This work was erected near the historic center affected by the most active of the three large and ancient landslides that involved the southern slope. The landslide that led to the progressive abandonment of the town, began with the collapse of the main walls in December 1963, Craco began to be evacuated and part of the inhabitants moved downstream to Craco Peschiera. In 1972 a flood further worsened the situation, preventing a possible repopulation of the historic center and after the 1980 earthquake, Craco was definitively abandoned.

The positioning of sensors has highlighted that the historic center is today in stable conditions.




Today only ruins remain of the ancient village: the only fairly intact buildings are those built in the highest part, above the natural rocky outcrop, while most of the building is reduced to rubble; dangerous buildings with deep cracks and structural instabilities that have profoundly compromised their stability, making their safety extremely complex.

This large artifact is presented today as a single composition, a sculpture clinging to a ridge of a massif that rises majestically in the surrounding valleys. The central idea for Craco 'ghost town', like many other realities of our south lost in the oblivion of abandonment, occupies an important position in international research. In particular, in the collective imagination and in that of many directors and photographers [I], Craco represents a mysterious and elusive opportunity for experience between life that has flowed into a place and the charm that this can exercise because it is dramatically abandoned. Craco has grown with an incredible strength of resistance and belonging to the site, between pinnacles of rock and clay ridges, becoming more than ever the archetype of the ghost town: burned by the sun and by the harsh winters, a single body of houses and palaces clinging to each other according to a composition that appears expressive and fascinating, almost a sculpture of uncovered houses, interrupted vaults and ruined bell towers.

The design experimentation tries to tear this place from a present that does not belong to it, trapped between the folds of the past and the time of abandonment. This character and the nature of the place can change precisely through the prefiguration in the search for a new life, a transformation into a different organism that can welcome and mend, transmit deep emotions and allow thousands of tourists to dive every year after a difficult trip, guided by the discovery, sometimes curiosity, in the wonderful experience of this 'ghost town'.

The interiors of the houses still contain elements of daily life and tell interrupted stories: bottles covered with dust on cold fireplaces, chairs and wicker baskets worn by time, tell of families around the hearth and domestic spaces lived according to the rhythms of nature, of the seasons, crops and animals. Pinnacles and peeks lined with sparse majolica tiles, evoke a sober well-being, of a city capable of its beauty and monumentality, like the bell tower of the ancient church. This place, from which the initial inspiration of research and project derives, represents a human experience built and well defined over time to which our work attempts a plausible response to access the harmonies, the emotions accessible by everyone who will 'inhabit' it. (M.C.).






\section{Methodological premises and logical sense of the research}

Recognized as a geo-site of scientific interest, Craco places its foundations on sedimentary rocks (gravels, sands and clays) characterized by suggestive shapes and in the surroundings, river terraces and gullies draw the landscape in a suggestive way. Architecture can, through new 'interweaving forms', attempt actions and identify artifacts to re-sew these deep wounds. Relating to the memory of this ancient plant in order to continue to frequent it, means structuring places of a journey of knowledge of human history which, through the project response, prefigures adequate and sustainable solutions.

The knowledge and understanding of the origins and history of the instability, thanks also to the collaboration with geological colleagues, were the starting point for devising 'aware' architectures, capable of measuring themselves with the deep characteristics of the place. The research and design experimentation attempts to re-draw paths of re-connection through small architectures and signs, almost like events, which allow to discover the flow of human work, identify the traces of each person who has attended in history an environment, an alley, a house, a church, a palace, the Norman watchtower. Everything can be observed to understand a particular value of the history of its existence.

The architectural project, starting from a wider research on the territories and fragile heritages of this land [2], tries to prefigure something intangible but present, mysterious but perceptible, to re-configure a possible transformation that opens up new opportunities for cultural, tourist and economic enhancement.

The drawings try to imagine and conceive a widespread system of small shelters that can allow visitors the most sublime of experiences: living among the ruins and falling asleep under the uncovered vaults of a ghost town, among the ancient ruins and the badlands of these lands. New temporary shelters in wood and iron, between the plots of steep roads and stony paths, between walls reduced to sails, blue skies and starry nights.

The project is articulated through a representative itinerary of images in a walk that with 'lightness' and a concrete 'consistency' runs through places and remains of cities. The great work of the artefacts and the mountain are a still and dramatic horizon, but the path and elements of the crossing are in constant transformation, in an incessant virtue of moving the look.
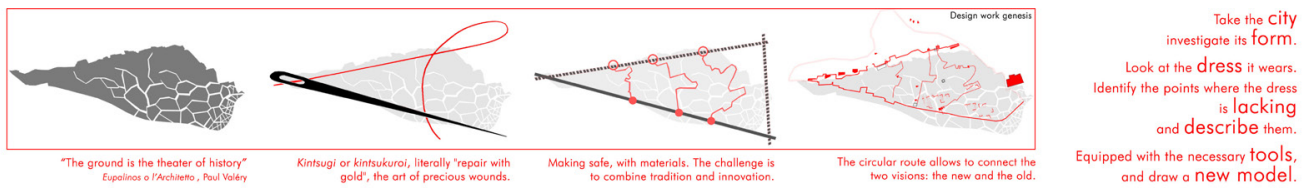
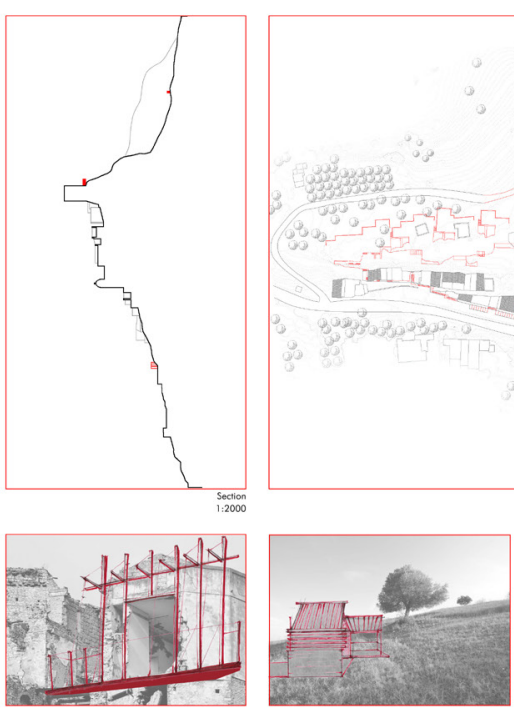
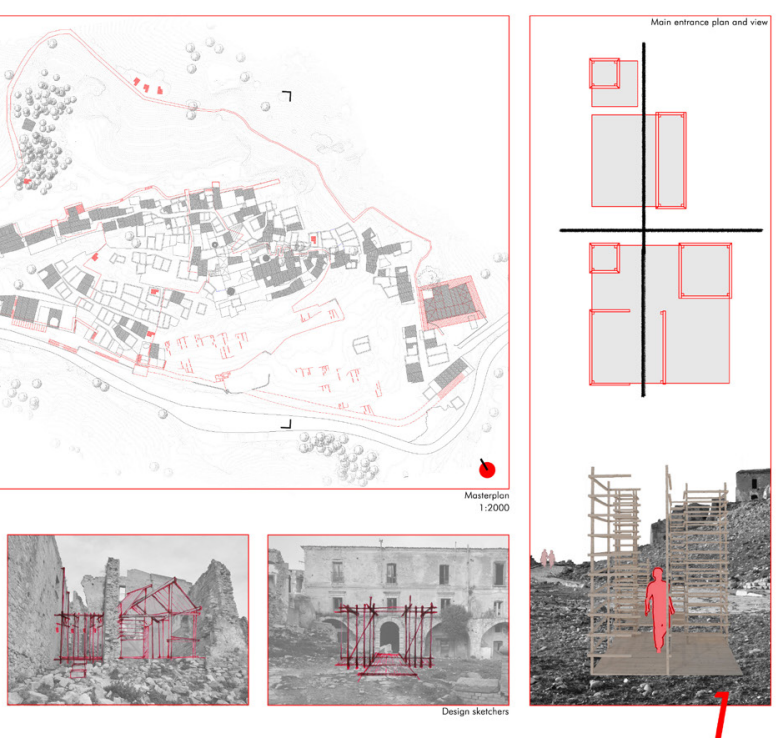
The change in the shape of the city due to catastrophic events, both natural and anthropogenic, represents one of the themes on which the architect is called to reflect more frequently today. The issue of Heritage crosses every contemporary research and project work. In these cases, the loss of the role of the cities in these fragile, destroyed and abandoned lands, which lose their vocation as places of living, to become places for the quick visit of the tourist or for the stop of the attentive traveler, is recorded. One wonders, then, what is the sense of re-inhabiting these places whose stones and architecture tell very ancient stories. The stones of the architectures that compose these urban centers are threads of an embroidery of the memory of places, interweaving of stories, networks of relationships, laces and knots that join pieces of incredible life and history held together by the Architecture project.

This ideation of the project does not concern the graphic contents or the sign, but a sort of accumulation of the knowledge that the trajectories of the paths and views will put the visitor to connect with the memory and art fixed forever in the materials and factories, aware of what Paul Valéry said that "the ground is the theater of history". (A.C.).
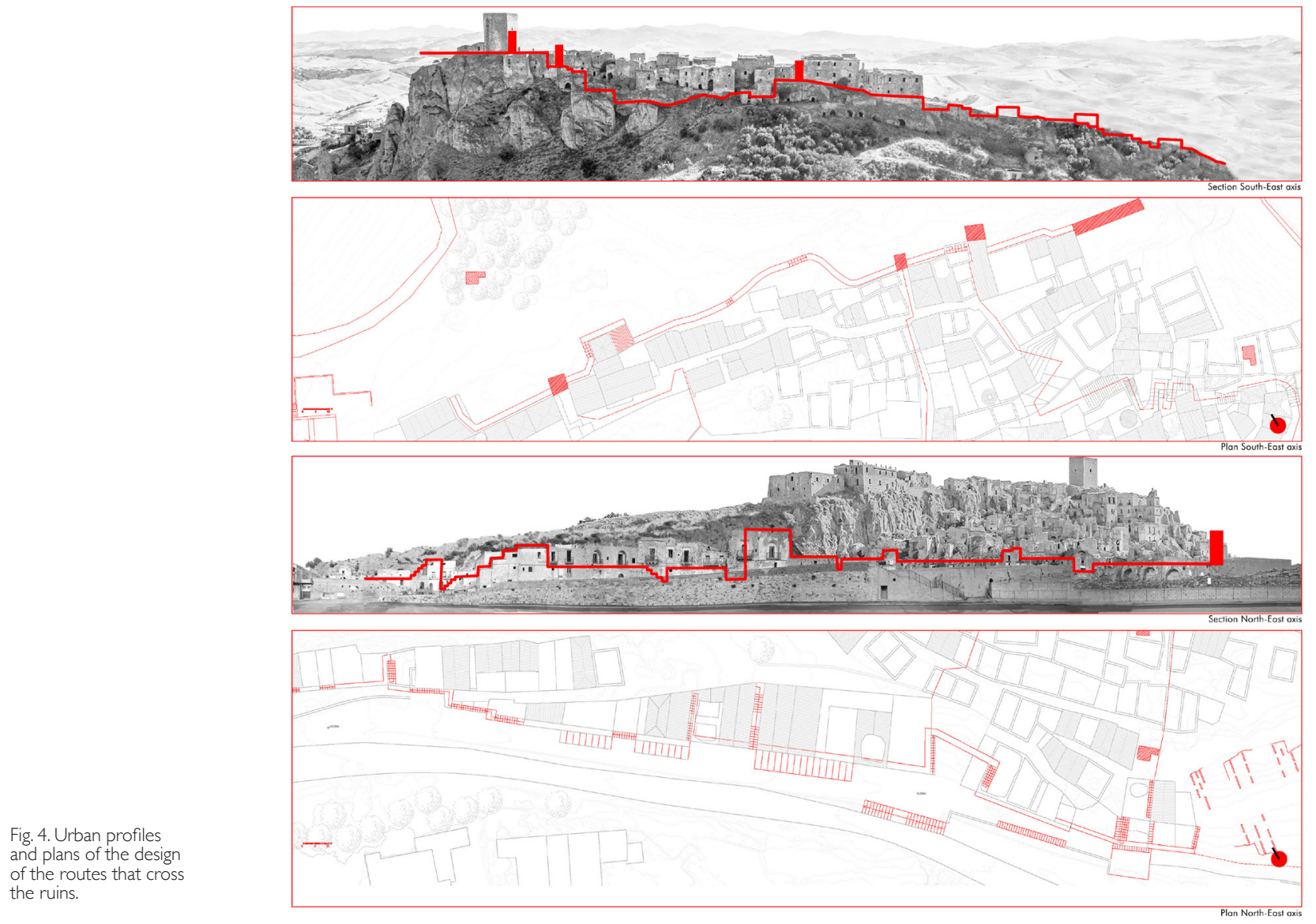

\section{Re-drawing project to re-stitch memories of an ancient city}

The genesis and evolution process of this research project, stems from the recognition of the memory of places as foundational and characteristic 'urban facts', declining the project of mending ruined architecture, using contemporary and sustainable construction methods. We intend to reinterpret the gesture of 'mending the city' through temporary works and safety measures, designed by studying forms and models recognizable in the traces of the memory of the places. 
The gesture of 'mending' parts of the broken city, refers to an ancient Japanese practice: kintsugi, which highlights the fractures, embellishes them and adds value to the broken object; 'kin' means gold and 'tsugi' reunification.

We intend to embrace the damage, highlight the fracture lines, embellish and add value to the architectural and urban object, making fragility a strength and perfection point. By choosing to repair what has been damaged, not only is its value recognized, but an even stronger attachment to its matter develops. Intricate and dense is the embroidery of the circumstances, the artifacts and the alleys that make up the nucleus and the urban ridge of Craco as well as numerous historical centers of Basilicata and Southern Italy.

The objectives of the project are the usability of the city through the construction of temporary consolidation works, which at the same time act as a 'space' to be crossed safely, and enhancement intended as an experiential and testimonial act of traveling an ancient feeling of life among the impassable alleys and made unrecognizable by the collapses. Currently the site has a single route of safe travel, which comes close to the Norman tower. It is a unique path, from which it is not possible to appreciate the complex and articulated historical topography of the places. The usability that is intended to be achieved with the project, aims to overcome the objective difficulties of reaching some points of the ghost town, so the provisional works are entrusted with the task of guaranteeing safety for those who travel through the places. Wooden arches, struts, hoops, decks, small scaffolding, these are some of the 'machines' used to climb the remains of the ancient streets of Craco. These long and articulated wooden devices that graze, support and in some cases, wrap and cross the fragile walls of some small houses, open, where the surrounding conditions allow it, to small wooden shelters, light shelters for the night, from which to observe the starry vault away from the city lights. The character and simplicity of installation, the technique of working beams, rafters and uprights in Turkey oak and spruce, returns the lost dialogue with the building tradition. It follows that temporary works no longer appear only at the time of construction and maintenance of the buildings, but become 'space' and an opportunity to enhance places that are difficult to reach. The artifacts designed as temporary works, work and graft through the concept of 'suspen-

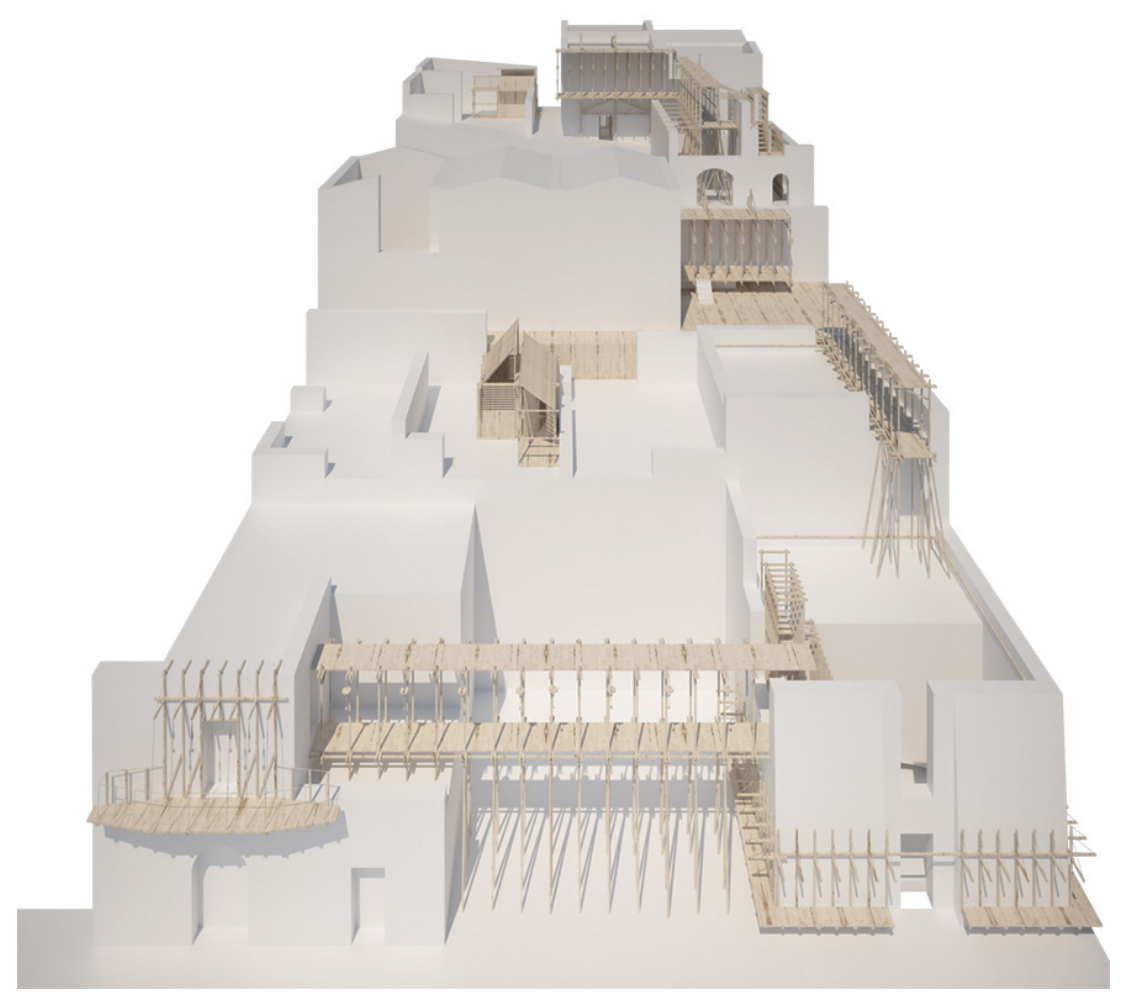



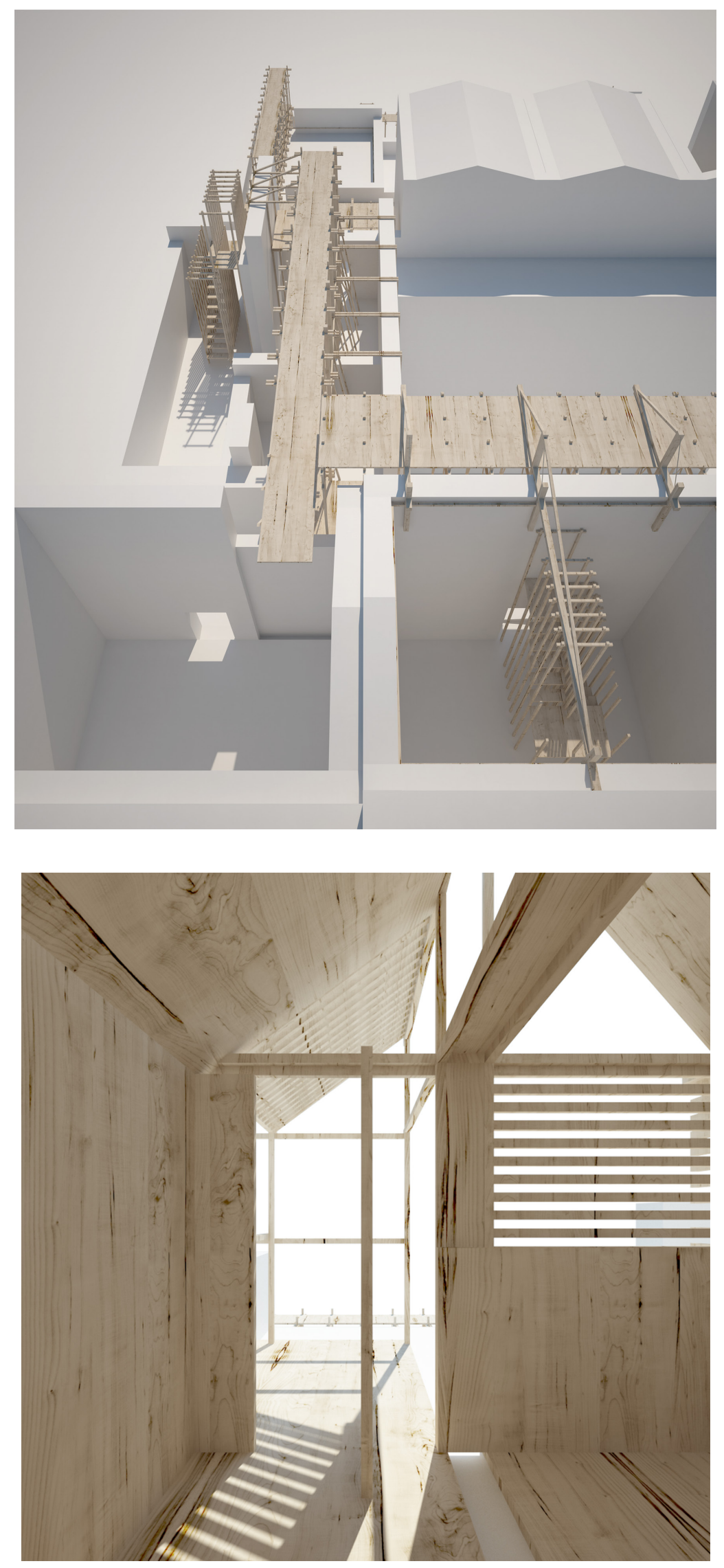
sion' and 'lightness' between the wrecks, alleys and streets, the skeletons of the houses, the flattened earth of rubble of the remains of architecture, materials of the art of building, which once inhabited these places.

After investigating the shape of the city and the materials of which it is composed, the project focused on the study and creation of three-dimensional prototypes to design devices for crossing and consolidating architectures and ruins, which can also be replicated in other areas having similar recognized characters.

The project is articulated, therefore, through the definition of routes through the entire historic center, which lead to temporary resting places for the traveler, small shelters, spaces for refreshment and contemplation of the landscape and the design of small rooms built in continuity with rock grooves, in the most statically solid part which is also the most suggestive point of view on the valley below.

The landscape is an anthropic construction in progress, in constant evolution. The project, its conception, works on physical limit between architecture and shape of the city (landscape), to graft contemporary architecture between the folds of the rock that composes it. Go beyond physical and historical limit through the natural landscape.

Therefore, fragments of light micro-architectures in wood and corten steel emerge from the rock which, with the new conception and transformation of the use of this heritage, of these architectures, are configured as grafts and interweaving in a continuum with the construction of the ancient city.

To the south of the old town, near the municipal road Craco-Montalbano Jonico, there is a large building on three floors. Its strategic position and dimensions suitable to accommodate a considerable number of people, give it the character of a public space with mixed accessory services such as tourist reception, restaurant, library and exhibition space. This building, still structurally intact, maintains its overall formal and material conformation, supplemented by temporary wooden works that enrich and articulate the building, ensuring a harmonious design between historic architecture and surrounding landscape. A light structure, in intertwined wooden slats, surrounds the ground floor becoming the surrounding wall and base of the entire building which acquires formal visibility and tectonic support; it also contaminates the internal spaces and distributes their geometries and intended uses.

In the opposite part of the old city, to the north and adjacent to the ridge, three shelters take shape to host visitors. The existing rock collaborates in the modeling of the architectural spa-

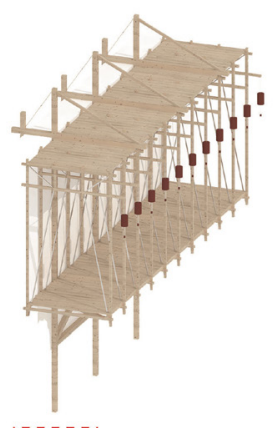

บบบ

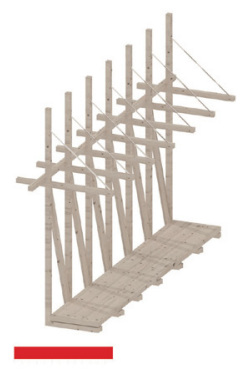

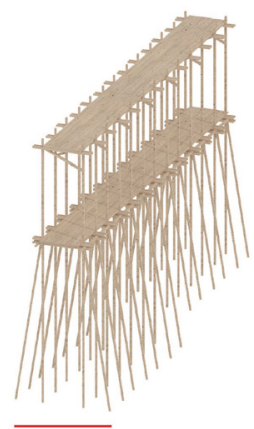
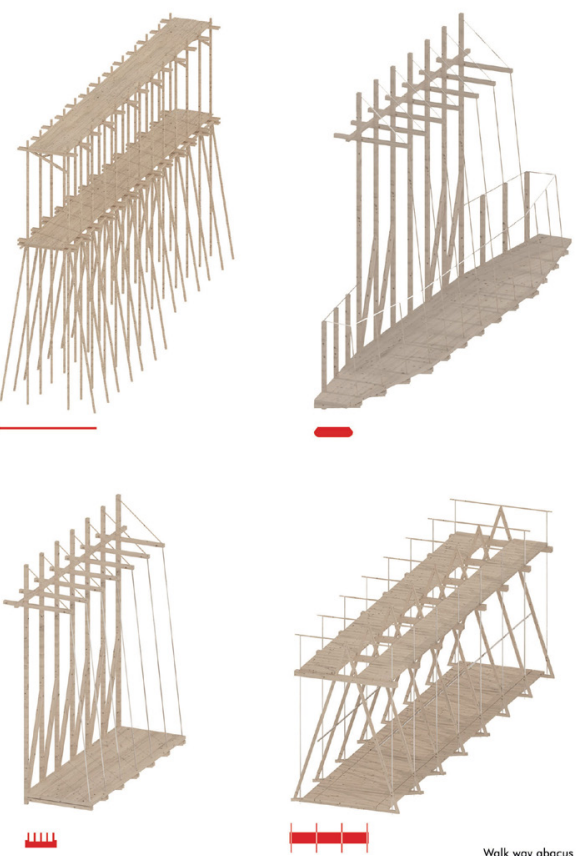

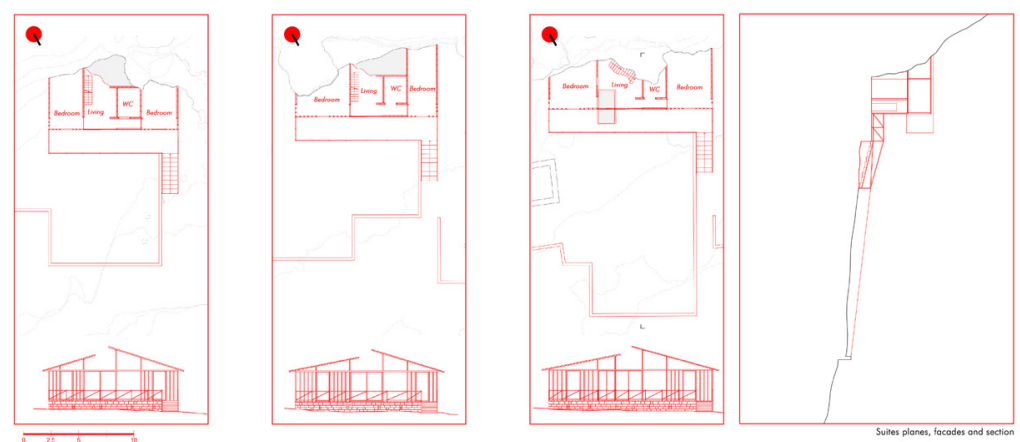

New Architectures arise from the rock, as the construction of the city was born from it.

The refuge by its nature, is nothing more than 9iphysical Architecture

The contact with the earth. Built and natural part.
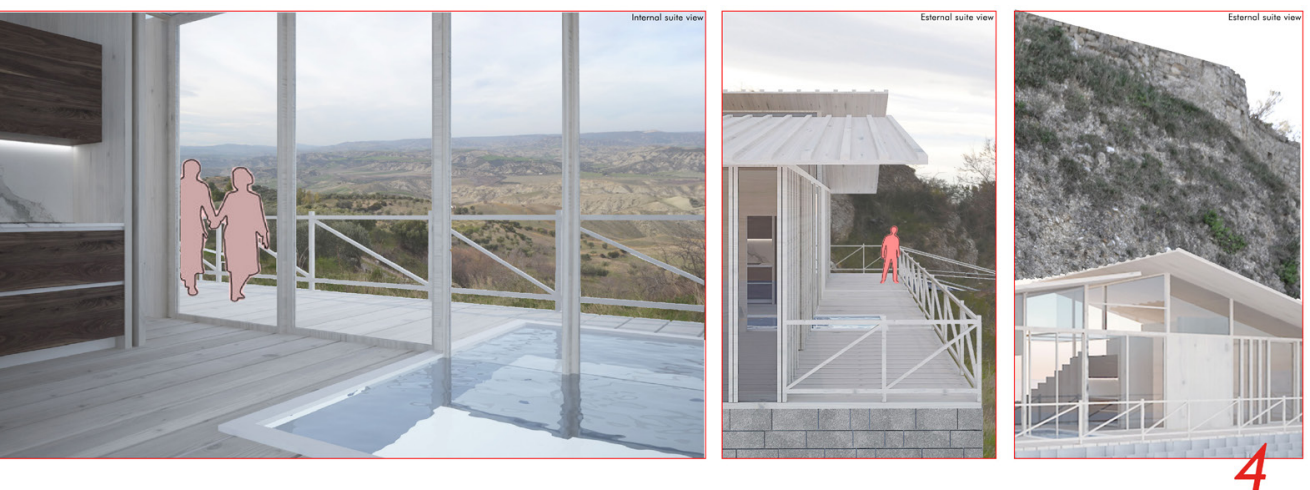

ce, which appropriates and forms its shape. The new wooden structure, therefore, was born and articulated clinging to the material of the place, following the same principle of the architecture of the Lucanian cities, when it was built in harmony with the territory, subtracting and adding the same material to build 'collaborating with the land'. (R.P., M.T.)
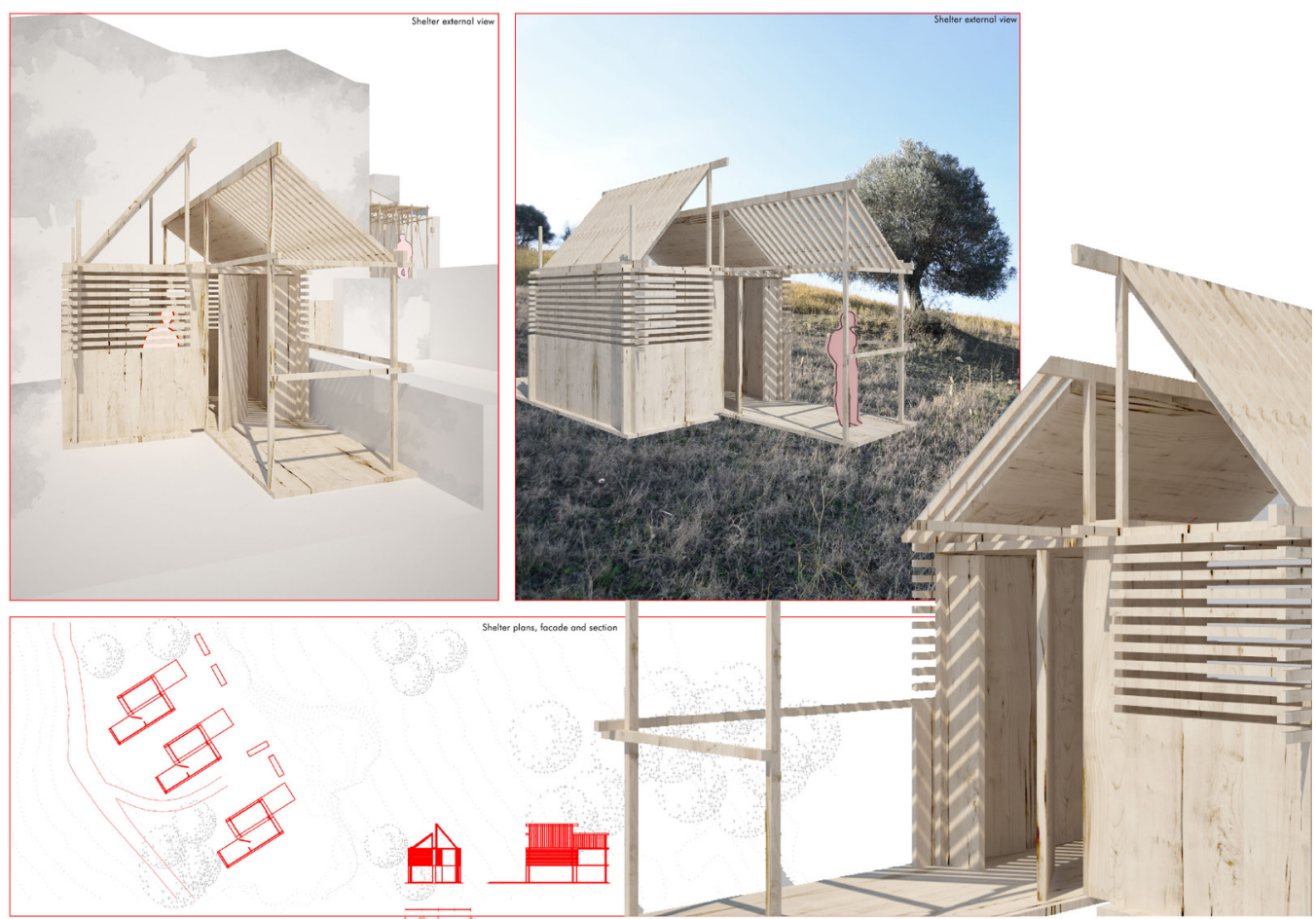


\section{Notes}

[I]We remember scenes from Mel Gibson's "The Passion of Christ" and from Marc Forster's "Quantum of Solace", registered in Craco territories.

[2] The research is part of a project experimentation activity conducted within the Design Laboratory 5: "Architecture and Heritage of the Constructed" and within the module: "Form and knowledge of the architectural heritage, of DiCEM Department of Matera, University of Basilicata. The theme of the laboratory is "Architecture and fragile heritage of ancient path in Basilicata". The PhD students Roberto Blasi, Roberto Pedone and Margherita Tricarico and the architects Rossella Laera, Anna Lovino, Mara Manicone, Lucia Nardiello and Francesca Sbano, contributed in various ways to the achievement of the objectives and to the drafting of the text and images in this essay. The entire work is coordinated by prof. Arch. Antonio Conte and Ph.D. Arch. Marianna Calia, director and tutor of the Laboratory.

\section{Rieferences}

Pedío Tommaso (1990). Centri scomparsi in Basilicata. Potenza: Osanna Edizioni.

Pasolini Pier Paolo, Brunatto Paolo (1973). Orte. La forma della città. docu-film RAl.

Martí Arís Carlos (201 I). La cèntina e l'arco. Pensiero, teoria, progetto in architettura. Milano: Christian Marinotti Edizioni.

\section{Authors}

Marianna Calia, Università della Basilicata, marianna.calia@unibas.it

Antonio Conte, Università della Basilicata, antonio.conte@unibas.it

Roberto Pedone, Università della Basilicata, roberto.pedone@unibas.it

Margherita Tricarico, Università della Basilicata, margherita.tricarico@unibas.it

To cite this chapter. Calia Marianna, Conte Antonio, Pedone Roberto, Tricarico Margherita (2020). Forme dell'intreccio per ri-cucire memorie di antico impianto in Basilicata/Twine forms to re-stitch memories of an ancient plan in Basilicata. In Arena A., Arena M., Brandolino R.G., Colistra D., Ginex G., Mediati D., Nucifora S., Raffa P. (a cura di). Connettere. Un disegno per annodare e tessere. Atti del $42^{\circ}$ Convegno Internazionale dei Docenti delle Discipline della Rappresentazione/Connecting. Drawing for weaving relationships. Proceedings of the 42th International Conference of Representation Disciplines Teachers. Milano: FrancoAngeli, pp. 975-994. 